\title{
無電解ニッケルータングステンーボロン合金めっき皮膜の 電気抵抗特性について
}

\author{
青木 公二*, 鷹 野 修*
}

\section{Resistance Characteristics of Electroless Ni-W-B Alloy Films}

Koji AOKI* and Osamu TAKANO*

Key Words : Electroless Plating, Ni-W-B Alloy, T. C. R.

\section{1. 緒言}

ジメチルアミンボラン(DMAB)を還元剂とする浴か らめっきする無電解Ni-W-B合金皮膜の電気抵抗特性に

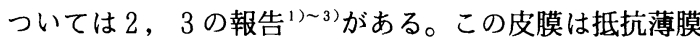
としては比較的抵抗值の低い部類に属する皮膜であるが, ち密で析出初期(300 ̊) から均一な皮膜となる特長を あっている。しかし，抵抗温度係数(TCR)につい ての研究は見当たらない。そこで, 本研究は無電解 Ni-W-B合金めっきの浴条件を検討し，その好適条件を 決定するととあに，得られた各皮膜の比抵抗，抵抗温度 特性などの電気抵抗特性を中心に調べ, さらに皮膜組成 との関連性を比較検討することを目的とした。

\section{2. 実験方法}

表 1 は予備実験によって求めた標準浴条件である。こ の条件下において浴中の $\mathrm{NiSO}_{4}$ と $\mathrm{Na}_{2} \mathrm{WO}_{4}$ の合計濃度 を0.1Mと一定にして $\mathrm{Na}_{2} \mathrm{WO}_{4} / \mathrm{NiSO}_{4}+\mathrm{Na}_{2} \mathrm{WO}_{4}$ モ 比を $0,0.025,0.05,0.1,0.2,0.3,0.4$ となるよう変 化させてめっきを行い各種組成をむつ合金皮膜を作製し た。素地には銅板を用い, 析出速度は10分間の膜厚 $(\mu \mathrm{m})$ で示し, 皮膜中のW含有量はけい光X線法で, また, B含有量は皮膜を硝酸に溶解した後, マンニット 法 $^{4)}$ により求めた。また, 比抵抗および抵抗温度係数測 定用には別にアルミナ基板を使用し，二液型活性処理 ${ }^{5)}$ を施した後, $2 \mu \mathrm{m}$ のめっきを行った。皮膜の比抵抗は 前報 ${ }^{6)}$ と同様にして四点探針法によって測定した。さら に, めっきしたままの皮膜および $300^{\circ} \mathrm{C}, 600^{\circ} \mathrm{C} て ゙ 1$ 時間 真空中（10 ${ }^{-4}$ torr） で熱好理した後炉内で徐冷した皮膜 をホトエッチングによりパターニングし, 皮膜抵抗を測 定した。また, 同一試料を $25^{\circ} \mathrm{C} \rightarrow 90^{\circ} \mathrm{C} \rightarrow 150^{\circ} \mathrm{C} \rightarrow 25^{\circ} \mathrm{C}$ と 各温度で30分間保持した後, 各温度における皮膜抵抗を 測定し, 抵抗の変化率から次式を用いて抵抗度係数 (TCR)

*姫路工業大学（テ671-11 兵庫県姫路市書写2167）

Himeji Inst. of Tech. (2167, Shosha, Himeji-shi, Hyogo 671-22)
Table 1 Bath compositions and plating conditions of electroless $\mathrm{Ni}-\mathrm{W}-\mathrm{B}$ alloy films

\begin{tabular}{c|c|c|c|c|c|c|c}
\hline$\frac{\mathrm{Na}_{2} \mathrm{WO}_{4}}{\mathrm{NiSO}_{4}+\mathrm{Na}_{2} \mathrm{WO}_{4}}$ & 0 & 0.025 & 0.05 & 0.1 & 0.2 & 0.3 & 0.4 \\
\hline $\mathrm{NiSO}_{4}(\mathrm{M})$ & 0.1 & 0.0975 & 0.095 & 0.09 & 0.08 & 0.07 & 0.06 \\
\hline $\mathrm{Na}_{2} \mathrm{WO}_{4}(\mathrm{M})$ & 0.0 & 0.0025 & 0.005 & 0.01 & 0.02 & 0.03 & 0.04 \\
\hline $\mathrm{DMAB}^{(\mathrm{g} / \mathrm{L})}$ & \multicolumn{5}{|c}{3} \\
\hline $\mathrm{Na}_{3} \mathrm{C}_{6} \mathrm{H}_{5} \mathrm{O}_{7}(\mathrm{M})$ & 0.2 \\
\hline $\mathrm{H}_{3} \mathrm{BO}_{3}(\mathrm{M})$ & 0.5 \\
\hline $\mathrm{C}_{7} \mathrm{H}_{4} \mathrm{NNaO}_{3} \mathrm{~S}(\mathrm{~g} / \mathrm{L})$ & 3 \\
\hline $\mathrm{pH}$ & \multicolumn{5}{c}{7 (with NaOH) } \\
\hline temp. & \multicolumn{5}{c}{$70 \pm{ }^{\circ} \mathrm{C}$} \\
\hline
\end{tabular}

を求めた。

$\mathrm{TCR}=\left(R_{(50)}-R_{(25)}\right) / R_{(25)} \times 10^{6} / 125\left(\mathrm{ppm} /{ }^{\circ} \mathrm{C}\right)$

\section{3. 実験結果および考察}

\section{1 析出速度およひ皮膜組成}

DMAB還元の無電解めっき皮膜はクラックが発生し やすいため応力緩和剤としてサッカリンナトリウムを 3 g/Lをすべての浴に添加した。

また, 浴中へのサッカリンナトリウムの添加は析出速 度を若干低くする傾向があるが，析出皮膜組成に対する 影響は殆ど見られなかった。 $\mathrm{Na}_{2} \mathrm{WO}_{4}$ 無添加のNi-B合 金めっき浴で, $\mathrm{pH} 7$ から 9 まで増加させると, 析出

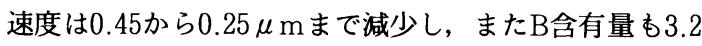
wt\%から2.1wt\%まで減少した。この場合, Ni-B合金 めっき皮膜はすべて顕微鏡観察の結果, クラックの発生 は見られなかった。析出速度, B含有量の比較的大きな $\mathrm{pH} 7$ の条件で $\mathrm{Na}_{2} \mathrm{WO}_{4}$ を添加した合金めっき浴からの 析出皮膜では $\mathrm{Na}_{2} \mathrm{WO}_{4}$ モル比0.2，0.3の浴では顕微鏡観 察の結果, サッカリンナトリゥムを添加してもクラック の発生がみられたが, $0,0.025,0.05,0.4$ の浴ではク ラックの発生が無くなった。

つぎに, Ni-W-B合金めっき浴中における金属イオン 濃度比を変化させた場合の析出速度ならびに析出皮膜組 


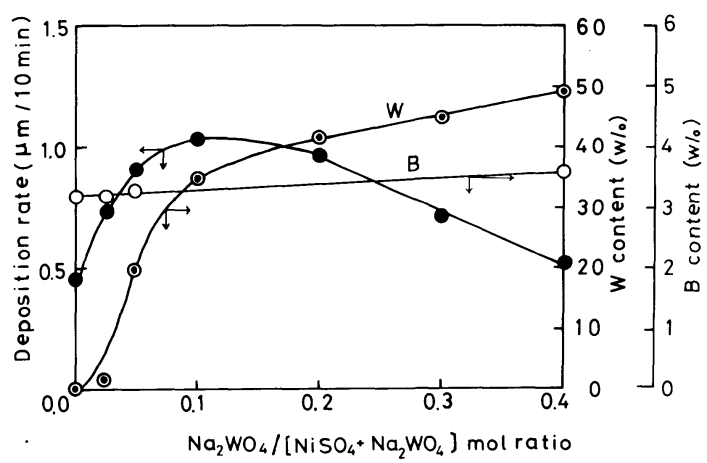

Fig. 1 Effect of molar ratio of metal ions on deposition rate and $\mathrm{B}, \mathrm{W}$ content of electroless Ni-W-B alloy films.

成の関係を調べ，その結果を図 1 に示した。

図から析出速度は浴中の $\mathrm{Na}_{2} \mathrm{WO}_{4}$ モル比が 0.1 までは 増加するが，それ以上になると減少する傾向が見られた。 即ち, $\mathrm{Na}_{2} \mathrm{WO}_{4}$ モル比0.1のあたりが反応性に富む浴条 件といえる。W含有量については $\mathrm{Na}_{2} \mathrm{WO}_{4}$ モル比 0.1 ま で急激に増加(35wt\%まで)するが，それ以上ではゅる やかに増加している。なお，B含有量は $3.2 w t \% か ら 3.6$ wt\%とあまり変化していない。

\section{2 皮膜の電気抵抗特性}

図 2 にNi-W-B合金めっき皮膜(膜厚 $2 \mu \mathrm{m}$ )のW含有 量とTCRの関係を示した。めっきのままの試料におい てW含有量が増加するほどTCRの変化は小さくなって いる。しかし, W含有量の少ない皮膜では未処理のTCR の值は $230 \mathrm{ppm} /{ }^{\circ} \mathrm{C}$ と大い。 $300^{\circ} \mathrm{C}, 600^{\circ} \mathrm{C}$ 熱処理を 行うと温度が増すに従って皮膜の結晶化により TCRの值は3000付近まで大きくなっている。しかし， W含有量が $20 \mathrm{wt} \%$ を越えると急減し，その值は $600^{\circ} \mathrm{C}$ の 皮膜ほど大きい。そして，W含有量の多い皮膜（49.3 $w t \%)$ では $300^{\circ} \mathrm{C}$ 熱処理で TCRは $15 \mathrm{ppm} /{ }^{\circ} \mathrm{C}$ と最も小 さい値を示した。

アモルファス合金であ述べられている7)ように，比抵 抗とTCRとの間には, 逆比例の関係がある。このこと は，図には示していないが，W含有量が増すほど，比抵 抗が小さくなった事実と一致している。

Ni-W-B合金めっき皮膜においては熱的に安定性が良 いため $300^{\circ} \mathrm{C} て ゙ は$ 結晶粒の成長が起こらずTCRは小さい が, $600^{\circ} \mathrm{C}$ にると結晶粒子の成長により比抵抗值が低 下すると同時にTCRが大きくなったものと考えられる。

\section{4. 結 論}

以上の実験結果より無電解Ni-W-B合金めっき皮膜の

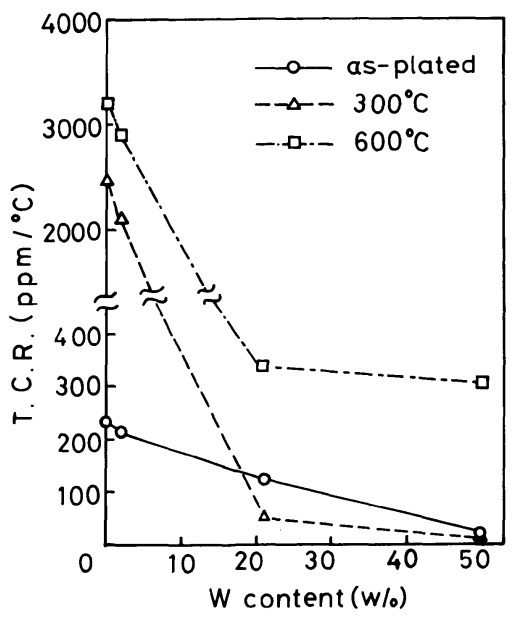

Fig. 2 T. C. R. vs. W content of deposits $(2 \mu \mathrm{m})$ as-plated and heat-treatment at $300^{\circ} \mathrm{C}, 600^{\circ} \mathrm{C}$ in $1 \mathrm{~h}$ (vacuum).

電気抵抗特性について次のことが明らかとなった。

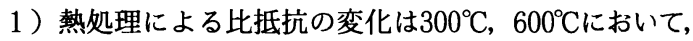
いずれの皮膜も比抵抗值は小さくなる傾向にあるが, W 含有量が高い皮膜では, 熱安定性, Wの状態などにより 一般に高い比抵抗值を示した。

2) TCRについて，W含有量が多く，B含有量が少な い皮膜ほどTCRの小さいことがわかった。

3 ）さらに, W含有量の多い皮膜（W含有量 $49.3 \mathrm{wt} \%$ ) では $300^{\circ} \mathrm{C}$ 熱処理でTCR $15 \mathrm{ppm} /{ }^{\circ} \mathrm{C}$ と最む小さい値 を示した。

(1990-1-16 受理)

本論文の非SI単位のSI単位に対する換算表

\begin{tabular}{c|c|c}
\hline \multicolumn{1}{c|}{ 量 } & 単位記号 & SI単位による值 \\
\hline モル濃度 & $\mathrm{M}$ & $1 \mathrm{M}=1 \mathrm{~mol} / \mathrm{L}$ \\
\hline 長 さ & $\mu \mathrm{m}$ & $1 \mu \mathrm{m}=10^{-6} \mathrm{~m}$ \\
\hline 温 度 & ${ }^{\circ} \mathrm{C}$ & $t^{\circ} \mathrm{C}=T(\mathrm{~K})-273.15$ \\
\hline
\end{tabular}

\section{文献}

1）逢坂折爾，澤井秀夫，笠井直記 ; 金属表面技術，32，615 (1981)

2 ）逢坂哲彌，斎藤 生 ; 表面技術，40，1097（1989）

3 ) 逢坂哲恓, 堌㴊長則, 本間敬之, 府川 真 ; 表面技術協会 第80回溝演大会講演要旨集, p.204（1989）

4 ）柴田雄次, 木村健二郎; 無機化学全書X-2, p.53（丸善, 1965)

5) I. Feldstein ; Plating, 54, 1035 (1967)

6）鷹野 修, 青木公二; 金属表面技術，34，316（1983）

7) 増本 健, 樑道和明 ; アモルファス合金, p.215（アグネ, 1981) 